Pak. j. sci. ind. res. Ser. A: phys. sci. 201558 (3) 157-171

\title{
Adsorption Performance of Modified Nkalagu Bentonite in Dye Removal: Kinetics, Equilibrium, Thermodynamics and Structural Properties of the Modified Samples
}

\author{
Regina Obiageli Ajemba \\ Department of Chemical Engineering, Nnamdi Azikiwe University, P.M.B. 5025, \\ Awka, Anambra, Nigeria
}

(received February 3, 2014; revised August 14, 2014; accepted August 15, 2014)

\begin{abstract}
The adsorption performance of modified Nkalagu bentonite in removing Congo red (CR) from solution was investigated. The raw bentonite was modified by three different physicochemical methods: thermal activation (TA), acid activation (AA), and combined acid and thermal activation (ATA). The Congo red adsorption increased with increase in contact time, initial dye concentration, adsorbent dosage, temperature, and $\mathrm{pH}$ change. The results of the kinetics analysis of the adsorption data revealed that adsorption follows pseudo second-order kinetics. Analysis of the equilibrium data showed that Langmuir isotherm provided a better fit to the data. Evaluation of the thermodynamic parameters revealed that adsorption process is spontaneous and endothermic. The results from this study suggest that a combination of thermal and acid activation is an effective modification method to improve adsorption capacity of bentonite and makes the bentonite as low-cost adsorbent for removal of water pollutants.
\end{abstract}

Keywords: adsorption, bentonite modification, kinetics, equilibrium, thermodynamics, dye removal

\section{Introduction}

The effluent discharge by textile industries contains large amounts of dyes which are high in colour and presence of even very small amount of dye is highly visible and can be very toxic. The synthetic dyes are generally nonbiodegradable and difficult to remove, thus affect the human and the aquatic life (Bulut et al., 2008). Various physical and biological methods have been employed for the treatment of dyes, including coagulation, flocculation, precipitation (Pandit and Basu, 2002), photo-catalysis (Kabra et al., 2004), oxidation (Jagatap and Ramaswamy, 2006), ozonation (Khadhraoui et al., 2009), etc. All these methods have some drawbacks, such as high operating cost, sludge production and complexity of the treatment processes. Adsorption is a widely used technique for the removal of dyes due to economical and environmentally friendly reasons (Jiuhui, 2008). The cost of removal of dyes by adsorption lies mainly in the cost of adsorbent and its regeneration. Activated carbon is the most widely used adsorbent due to its high surface area and adsorption capacity, but the use of activated carbon is becoming restricted due to its high cost and regeneration difficulties. Many low-adsorbents are developed worldwide to replace activated carbon. Generally, these low-cost adsorbents

E-mail: ginaajemba@rocketmail.com have a small surface area and a low adsorption capacity. Previous studies stated that the adsorption capability of the adsorbents can be enhanced by modification of these adsorbents via physical and chemical processes.

Clays are finding increasing application in wastewater as adsorbents due to their low-cost and good intrinsic adsorption characteristics, such as high adsorption capacity and large surface area. There are large numbers of clay minerals such as kaolin (Nandi et al., 2009), montmorillonite (Damardji et al., 2009; Yan et al., 2007), bentonite (Ozcan et al., 2005), clinoptilolite (Li and Bowman, 1997), smectite (Diaz et al., 2001), sepiolite (Kara et al., 2003) and zeolite (Vimonses et al., 2009) that are widely used for the costeffective removal of chemical pollutants from wastewater. Among all these clays, bentonite is one of the most widely used due to its abundant availability and good adsorption characteristics (Christidis et al., 1997). Adsorption capacity and selectivity of natural and or raw bentonite can be limited. Thus, a systematic surface modification of bentonite is essential for the removal of anionic compounds from wastewater since most of the dissolved chemical pollutants are negatively charged. There are various physical and chemical methods available for the modification of clays. These include acid activation (Steudel et al., 2009), treatment with cationic surfactants (He et al., 2006), thermal 
treatment (Al-Asheh et al., 2003), pillaring, de-lamination and re-aggregation of smectites (Paiva et al., 2008) and grafting of organic compounds (Liu, 2007). Among these methods, acid activation is one of the most commonly used modification techniques because it is a simple and low-cost process (Jovanovic and Jonackovic, 1990).

In this work, bentonite from Nkalagu was modified by thermal activation, acid activation and combined acid and thermal activation. The effects of these modifications on the properties of the bentonite were investigated. The modified samples were employed in the removal of Congo red (CR) from solution and effects of operating variables, such as initial dye concentration, adsorbent dosage, contact time and temperature were analysed. The adsorption data were analysed by fitting them with Langmuir, Freundlich, and Dubinin-Radushkevich adsorption isotherms. Also, the adsorption kinetics was investigated using pseudo-first order, pseudo-second order, Elovich and intra-particle kinetic models.

\section{Materials and Methods}

Materials. The bentonite used in this study was mined at the site at Nkalagu, Nigeria (N: $6^{\circ} 55^{\prime} 12.7^{\prime \prime}$; E: $6^{\circ} 47^{\prime}$ $34.3^{\prime \prime}$; A: $156 \mathrm{~m}$ ), separated from dirt and sun-dried for $48 \mathrm{~h}$. The dried bentonite sample was analysed to determine its chemical composition and physical properties. The physical properties determined were surface area, cation exchange capacity, density and acidity.

The Congo red used in this study was obtained from Conraws Chemicals, Enugu, Nigeria. The chemical formula is $\mathrm{C}_{33} \mathrm{H}_{22} \mathrm{~N}_{6} \mathrm{Na}_{2} \mathrm{O}_{6} \mathrm{~S}_{2}$ with colour index 22120 and molecular weight of $696.7 \mathrm{~g}$ mol. The stock solution of Congo red was prepared by dissolving known quantity of Congo red in ionised water, while successive dilutions were made to obtain the working solution of desired concentrations.

Modification methods. Thermal activation. The physical modification of the raw bentonite was performed by thermal activation. The preparation of the raw bentonite was done by calcination in a muffle furnace. The calcination was carried out over a temperature range from $100{ }^{\circ} \mathrm{C}$ to 600 ${ }^{\circ} \mathrm{C}\left(100,200,300,400,500\right.$, and $\left.600{ }^{\circ} \mathrm{C}\right)$. The process of thermal activation was done by measuring out $10 \mathrm{~g}$ of raw bentonite in a crucible and heating in the muffle furnace. The temperature of the muffle furnace was allowed to rise steadily to the desired value and the heating was done for varying times of $30 \mathrm{~min}$ to $2 \mathrm{~h}(30,45,60,90,115$, and $120 \mathrm{~min})$. At the completion of the time, the samples were withdrawn from the furnace and cooled in a desiccator for $2 \mathrm{~h} 30 \mathrm{~min}$. The thermal activated sample was labeled TA.

Acid activation. The raw bentonite was treated with sulphuric acid solution of varying concentrations $(0.25$, $0.50,0.75,1.00,1.25$ and $1.50 \mathrm{~mol} / \mathrm{L}$ ) and at a temperature of $60^{\circ} \mathrm{C} .10 \mathrm{~g}$ of the raw bentonite was reacted with $100 \mathrm{~mL}$ of known concentration of sulphuric acid solution in a rotary shaker with temperature and agitation control for $3 \mathrm{~h}$. At the completion of the reaction period, the reaction was terminated and the slurry was filtered. The acidified product was then washed several times with distilled water until the filtrate was free of sulphate ions. The residue was then dried in an oven at $80^{\circ} \mathrm{C}$ for $24 \mathrm{~h}$. The acid activated sample was labeled AA.

Acid and thermal activation. The acid and thermal activation of the raw bentonite was carried out in two stages. In the first stage the bentonite was acid activated with sulphuric acid and in the second stage the acid activated sample was further subjected to thermal activation. The acid and thermal activated sample was labeled ATA.

Characterisation of the raw and activated bentonite samples. The chemical compositions of the natural and activated clay samples were determined by using X-ray fluorescence (XRF), Philips PW 2400 XRF spectrometer. The surface area and cation exchange capacity of the treated and untreated samples were also determined by the following outlined methods:

Specific surface area. The surface area was determined using ethylene glycol mono-ethyl-ether (EGME) as described by Carter et al. $(1965 ; 1964)$. Clay samples were sun-dried and grounded to pass No. 40 sieve. A small amount of the sample was then placed in an oven at a temperature of $105^{\circ} \mathrm{C}$ overnight to remove water and then dried with $\mathrm{P}_{2} \mathrm{O}_{5}$. Dried sample $1 \mathrm{~g}$ was spread into the bottom of aluminium tare and weighed (Wa) using an analytical balance with an accuracy of $0.001 \mathrm{~g}$. Approximately $3.0 \mathrm{~mL}$ of laboratory grade EGME was added to the sample using a pipette and mixed together with a gentle swirling motion to create uniform slurry. All clay samples were covered with the EGME in order to obtain an accurate surface area measurement. The aluminium tare was then placed inside a standard laboratory glass sealed vacuum desiccator and allowed to equilibrate for $20 \mathrm{~min}$. The desiccator was then evacuated using vacuum pump. The aluminium tare was removed from the desiccator and weighed (Ws) after periods of 12,16 , and $24 \mathrm{~h}$, 
respectively. When the mass of the sample varied by more than $0.001 \mathrm{~g}$ between 2 measurements, the sample was placed back in the desiccator and evacuated again for an additional $2 \mathrm{~h}$. The process continued untill the sample mass did not vary by more than $0.001 \mathrm{~g}$. The surface area was expressed as follows:

$\mathrm{A}=\frac{\mathrm{Wa}}{0.000286 \mathrm{Ws}}$

Where:

$\mathrm{A}=$ surface area; $\mathrm{Wa}_{\mathrm{a}}=$ weight of EGME retained by the sample, $\mathrm{W}_{\mathrm{S}}=$ weight of $\mathrm{P}_{2} \mathrm{O}_{5}$-dried sample, 0.000286 is the weight of EGME required to form uni-molecular layer on a square meter of the surface (Chiou et al., 1993).

Cation Exchange Capacity (CEC) (Ingelthorpe et al., 1993). Clay sample $5 \mathrm{~g}$ was weighed into the 250 $\mathrm{mL}$ polythene bottle with a magnetic stirrer. The bottle and its contents were weighed $\left(\mathrm{M}_{1}\right) .100 \mathrm{~mL}$ of buffered barium chloride solution was added to the bottle and was placed on a magnetic stirring plate and agitated for $1 \mathrm{~h}$. At the end of the period, the bottle was centrifuged at $1500 \mathrm{rpm}$ for $15 \mathrm{~min}$ and the supernatant was discarded. Further, $200 \mathrm{~mL}$ of the buffered barium chloride solution was added and the mixture was agitated on a magnetic stirring plate for another $1 \mathrm{~h}$. The bottle and its contents were left overnight. The following day, the bottle and its contents were centrifuged at $1500 \mathrm{rpm}$ for $15 \mathrm{~min}$ and the supernatant discarded. $200 \mathrm{~mL}$ of distilled water was added and agitated for few minutes on the magnetic stirring plate. It was centrifuged for further $15 \mathrm{~min}$ and the supernatant discarded. The bottle and its contents were weighed $\left(\mathrm{M}_{2}\right) .100 \mathrm{~mL}$ of $\mathrm{MgSO}_{4}$ solution was pipetted into the bottle and stirred well and was left to stand for $2 \mathrm{~h}$, with occasional agitation on the magnetic stirring plate. After $2 \mathrm{~h}$, the contents were centrifuged at $1500 \mathrm{rpm}$ for $15 \mathrm{~min}$ and the supernatant decanted into the stopper bottle. $5 \mathrm{~mL}$ aliquot of this solution was transferred into a $100 \mathrm{~mL}$ conical beaker and $5 \mathrm{~mL}$ of ammonia buffer and 6 drops of indicator were added to it. This mixture was titrated with standard EDTA (titre $\mathrm{A}_{1} \mathrm{~mL}$ ). Another titration was done with a $5 \mathrm{~mL}$ of aliquot of $0.05 \mathrm{M} \mathrm{MgSO}_{4}$ solution (titre $\mathrm{B} \mathrm{mL}$ ). The end point was indicated by a blue to pink colour change. The cation exchange capacity (CEC) was calculated as follows:

$\mathrm{CEC}=8\left\{\mathrm{~B}-\frac{\left(\mathrm{A}_{1} \times\left(100+\mathrm{M}_{2}-\mathrm{M}_{1}\right)\right.}{100}\right\} \frac{\mathrm{meg}}{100 \mathrm{~g}}$
Where:

$M_{1}=$ weight of bottle plus dry content $(g), M_{2}=$ weight of bottle plus wet content $(\mathrm{g}), \mathrm{A}_{1}=$ titration end-point of sample $(\mathrm{mL})$, and $\mathrm{B}=$ titration end-point of $\mathrm{MgSO}_{4}$ solution $(\mathrm{mL})$.

Adsorption study. The adsorption study of the Congo red onto the raw and activated bentonite was studied in the following manner. A measured quantity of the activated bentonite was added to $100 \mathrm{~mL}$ solution of the prepared dye solution in $250 \mathrm{~mL}$ Erlenmeyer flasks. The mixture was agitated in an incubated shaker at a pre-determined temperature and speed for the desired time. At the completion of the reaction period, the supernatant was separated by centrifugation at $3000 \mathrm{rpm}$ for $15 \mathrm{~min}$. The residual concentration in the supernatant was determined. The dye concentration in the raw and treated sample was determined by UV-Vis spectrophotometer (model WFJ 525). The analyses were carried out at a wavelength of $496.5 \mathrm{~nm}$. The response, removal efficiency of malachite green by the activated bentonite, was calculated as:

$\mathrm{Y}(\%)=100 \frac{\mathrm{C}_{\mathrm{o}}-\mathrm{C}_{\mathrm{i}}}{\mathrm{C}_{\mathrm{o}}}$

Where:

$\mathrm{C}_{\mathrm{o}}$ and $\mathrm{C}_{\mathrm{i}}$ are the initial and final concentration of the dye solution.

The amount of equilibrium adsorption, $\mathrm{q}_{\mathrm{e}}(\mathrm{mg} / \mathrm{g})$, was calculated by:

$\mathrm{q}_{\mathrm{e}}=\frac{\mathrm{V}\left(\mathrm{C}_{\mathrm{o}}-\mathrm{C}_{\mathrm{e}}\right)}{\mathrm{M}}$

Where:

$\mathrm{C}_{\mathrm{o}}$ and $\mathrm{C}_{\mathrm{e}}(\mathrm{mg} / \mathrm{L})$ are the liquid-phase concentrations of dye at initial and equilibrium, respectively, $\mathrm{V}(\mathrm{L})$ is the volume of the solution and $\mathrm{M}(\mathrm{g})$ is the mass of dry prepared sorbent used.

Effect of process parameters. Effect of initial dye concentration. The effect of initial dye concentration on the equilibrium data of adsorption of Congo red on raw and modified bentonite samples, TA, AA, and ATA, was studied over a concentration range from $50 \mathrm{mg} / \mathrm{L}$ to $500 \mathrm{mg} / \mathrm{L}$. $200 \mathrm{mg}$ of adsorbent was added to $50 \mathrm{~mL}$ dye solution of pre-determined initial dye concentrations. The contents were agitated and after $24 \mathrm{~h}$ the dye concentration in the supernatant was determined by UV-Vis spectrophotometer.

Effect of contact time. In the study of the effect of contact time on the adsorption of Congo red on raw 
and modified bentonite samples, $200 \mathrm{mg}$ of adsorbent was added to $50 \mathrm{~mL}$ dye solution of initial concentration $(100 \mathrm{mg} / \mathrm{L})$. The contents were agitated in a rotary shaker. The agitation process was carried out for time range from $1 \mathrm{~h}$ to $24 \mathrm{~h}$. The flasks were taken out of the shaker at time intervals and the dye concentration in the supernatant was measured.

Effect of temperature. The effect of temperature on the adsorption of Congo red onto raw and modified bentonite samples was investigated at different temperatures range from 30 to $80^{\circ} \mathrm{C}$. $200 \mathrm{mg}$ of adsorbent was added to $50 \mathrm{~mL}$ dye solution with initial dye concentration of $(100 \mathrm{mg} / \mathrm{L})$. The contents were agitated for $24 \mathrm{~h}$ after which they were centrifuged and the concentration of dye in the supernatant was determined.

Effect of $\boldsymbol{p H}$. The effect of $\mathrm{pH}$ on the adsorption of Congo red on raw and modified bentonite was studied. A known amount of adsorbent was added to Congo red solution of desired $\mathrm{pH}$ value. The $\mathrm{pH}$ value of the initial dye solution was varied between 1 and 11. Samples were withdrawn and dye concentration of the supernatant determined.

Effect of adsorbent dosage. To study the effect of adsorbent dosage on the adsorption of Congo red onto raw and modified bentonite, amount of the adsorbent was varied in the range from 100 to $500 \mathrm{mg}$. A measured amount of adsorbent was added to $50 \mathrm{~mL}$ dye solution of initial concentrations of $100 \mathrm{mg} / \mathrm{L}$. The contents were agitated, centrifuged and the dye concentration of the supernatant determined by UV-vis spectrophotometer.

\section{Results and Discussion}

Characterisation of the activated bentonite. The results of the X-ray fluorescence analysis of the activated bentonite samples are shown in Tables 1, 2, and 3 for acid, thermal and acid/thermal activated samples, respectively. As can be observed from Tables 1 and 3, the octahedral cations such as $\mathrm{Al}^{3+}, \mathrm{Fe}^{3+}$, and $\mathrm{Mg}^{2+}$, reduced appreciably as the concentration of the acid treatment increased, while the tetrahedral cations, like $\mathrm{Si}^{4+}$, increased with severity of treatment. The behaviour showed by the $\mathrm{Al}_{2} \mathrm{O}_{3}, \mathrm{Fe}_{2} \mathrm{O}_{3}$, and $\mathrm{MgO}$ content with progressive acid treatment is related to the progressive dissolution of the bentonite minerals. The octahedral sheet destruction passes the cations into the solution, while the silica generated by the tetrahedral sheet remains in the solids, due to its insolubility. Pesquera et al. (1992) suggests that this free silica generated by the initial destruction of the tetrahedral sheet is polymerised by the effect of such high acid concentrations and is deposited on the undestroyed silicate fractions, protecting it from further attack. Apart from leaching out of the octahedral and tetrahedral cations, the acid activated samples showed a decrease in the cation exchange capacity and increase in the surface area with increase in the severity of treatment.

Table 2 shows results of the chemical composition of the thermally activated samples. The results show that the octahedral and tetrahedral cations increased in their values with severity of treatment while the loss on ignition decreased appreciably as temperature increased. The increase in the cations values as thermal treatment progressed could be attributed to complete removal of water and organic substances from the clay crystalline structure which created vacancies in the structure. The results of the cation exchange capacity of the activated samples show that the exchange ability of the activated samples decreased as the concentration of the acid and temperature used in the activation increased.

Table 1. Chemical composition of the acid activated (AA) clay samples as given by the X-ray fluorescence analysis

\begin{tabular}{llllllll}
\hline \hline $\begin{array}{l}\text { Chemical } \\
\text { constituents }\end{array}$ & \multicolumn{7}{c}{ Clay samples } \\
\cline { 2 - 8 } & NKG 0 & NKG 0.25 & NKG 0.50 & NKG 0.75 & NKG 1.00 & NKG 1.25 & NKG 1.50 \\
\hline $\mathrm{Al}_{2} \mathrm{O}_{3}$ & 27.82 & 19.34 & 11.16 & 3.81 & 4.9 & 5.24 & 5.75 \\
$\mathrm{SiO}_{2}$ & 43.64 & 59.75 & 68.66 & 78.45 & 77.32 & 77.12 & 77.03 \\
$\mathrm{Fe}_{2} \mathrm{O}_{3}$ & 18.25 & 12.81 & 6.23 & 1.84 & 1.98 & 2.03 & 2.11 \\
$\mathrm{MgO}$ & 2.43 & 2.01 & 1.07 & 0.21 & 0.09 & 0.06 & 0.02 \\
$\mathrm{Na}_{2} \mathrm{O}$ & 0.95 & 0.52 & 0.28 & 0.07 & 0.05 & 0.02 & 0.02 \\
$\mathrm{~K}_{2} \mathrm{O}$ & 0.61 & 0.25 & 0.09 & 0.02 & 0.02 & 0.02 & 0.02 \\
$\mathrm{CaO}$ & 0.62 & 0.41 & 0.17 & 0.05 & 0.03 & 0.01 & 0.01 \\
$\mathrm{TiO}$ & 1.67 & 0.75 & 0.33 & 0.11 & 0.09 & 0.06 & 0.05 \\
$\mathrm{LOI}$ & 4.01 & 2.74 & 1.06 & 0.74 & 0.65 & 0.51 & 0.48 \\
$\mathrm{Total}$ & 100 & 98.58 & 89.05 & 85.3 & 85.13 & 85.07 & 85.49 \\
$\mathrm{CEC}$ (meq/100g) & 56 & 49 & 42 & 27 & 28 & 29 & 30 \\
\hline \hline
\end{tabular}


Table 2. Chemical composition of the thermally activated (TA) clay samples as given by X-ray fluorescence analysis

\begin{tabular}{llllllll}
\hline \hline $\begin{array}{l}\text { Chemical } \\
\text { constituents }\end{array}$ & NKG 0 & NKG 100 & NKG 200 & NKG 300 & NKG 400 & NKG 500 & NKG 600 \\
\cline { 2 - 7 } & 27.82 & 27.94 & 28.00 & 28.57 & 28.58 & 24.58 & 24.58 \\
$\mathrm{Al}_{2} \mathrm{O}_{3}$ & 43.64 & 44.14 & 44.75 & 44.88 & 44.89 & 44.89 & 44.89 \\
$\mathrm{SiO}_{2}$ & 18.25 & 18.37 & 18.41 & 18.57 & 18.58 & 18.58 & 18.58 \\
$\mathrm{Fe}_{2} \mathrm{O}_{3}$ & 2.43 & 2.47 & 2.51 & 2.58 & 2.58 & 2.59 & 2.59 \\
$\mathrm{MgO}$ & 0.95 & 0.96 & 0.97 & 0.99 & 0.99 & 0.99 & 0.99 \\
$\mathrm{Na}_{2} \mathrm{O}$ & 0.61 & 0.64 & 0.66 & 0.71 & 0.71 & 0.71 & 0.71 \\
$\mathrm{~K}_{2} \mathrm{O}$ & 0.62 & 0.63 & 0.65 & 0.69 & 0.70 & 0.70 & 0.70 \\
$\mathrm{CaO}$ & 1.67 & 1.69 & 1.73 & 1.79 & 1.79 & 1.79 & 1.79 \\
$\mathrm{TiO}$ & 4.01 & 3.06 & 2.15 & 1.14 & 1.10 & 1.09 & 1.08 \\
LOI & 100 & 99.90 & 99.83 & 99.92 & 99.92 & 99.92 & 99.91 \\
$\mathrm{Total}$ & 56 & 53 & 47 & 38 & 34 & 32 & 31 \\
CEC (meq/100g) & & & &
\end{tabular}

Table 3. Chemical composition of the acid/thermal activated (ATA) clay samples as given by the X-ray fluorescence analysis

\begin{tabular}{llllllll}
\hline \hline \multirow{2}{*}{$\begin{array}{l}\text { Chemical } \\
\text { constituents }\end{array}$} & \multicolumn{7}{c}{ Clay samples activated at 300 ${ }^{\circ} \mathrm{C}$} \\
\cline { 2 - 8 } & NKG 0 & NKG 0.25 & NKG 0.50 & NKG 0.75 & NKG 1.00 & NKG 1.25 & NKG 1.50 \\
\hline $\mathrm{Al}_{2} \mathrm{O}_{3}$ & 27.82 & 17.44 & 9.10 & 1.21 & 2.10 & 2.28 & 2.75 \\
$\mathrm{SiO}_{2}$ & 43.64 & 64.95 & 72.75 & 82.15 & 81.24 & 81.22 & 81.20 \\
$\mathrm{Fe}_{2} \mathrm{O}_{3}$ & 18.25 & 10.51 & 4.20 & 0.74 & 0.86 & 0.92 & 0.94 \\
$\mathrm{MgO}$ & 2.43 & 2.01 & 1.07 & 0.21 & 0.09 & 0.06 & 0.02 \\
$\mathrm{Na}_{2} \mathrm{O}$ & 0.95 & 0.52 & 0.28 & 0.07 & 0.05 & 0.02 & 0.02 \\
$\mathrm{~K}_{2} \mathrm{O}$ & 0.61 & 0.25 & 0.09 & 0.02 & 0.02 & 0.02 & 0.02 \\
$\mathrm{CaO}$ & 0.62 & 0.41 & 0.17 & 0.05 & 0.03 & 0.01 & 0.01 \\
$\mathrm{TiO}$ & 1.67 & 0.75 & 0.33 & 0.11 & 0.09 & 0.06 & 0.05 \\
$\mathrm{LOI}$ & 4.01 & 1.64 & 0.96 & 0.64 & 0.60 & 0.49 & 0.43 \\
$\mathrm{Total}$ & 100 & 98.48 & 88.95 & 85.20 & 85.08 & 85.05 & 85.44 \\
$\mathrm{CEC}$ (meq/100g) & 56 & 44 & 39 & 23 & 26 & 29 & 31 \\
\hline \hline
\end{tabular}

With the increase of concentration of sulphuric acid, the bentonite showed a gradual decrease of the CEC until dissolving with $0.75 \mathrm{~mol} / \mathrm{L} \mathrm{H}_{2} \mathrm{SO}_{4}$. In treatment with $1.00 \mathrm{~mol} / \mathrm{L} \mathrm{H}_{2} \mathrm{SO}_{4}$, as the $\mathrm{SiO}_{2}$ content decreased, an increase of CEC was observed in comparison with the CEC observed with the sample treated with 0.75 $\mathrm{mol} / \mathrm{L}$. This is due to the removal of the exchangeable ions from the lattice of the clay samples by the acid hydrogen ion which occupies the vacant sites created by the removal of the octahedral and tetrahedral ions.

Surface area of the activated samples. The acid activation was carried out with sulphuric acid concentrations of 0.25 to $1.25 \mathrm{~mol} / \mathrm{L}$. Pushpaletha et al. (2005) reported that the surface area of activated bentonite generally increases with increase in concentration until a maximum surface area is reached after which it gradually decreases. In this study, the surface area was observed to increase with increase in acid concentrations from $0.25 \mathrm{~mol} / \mathrm{L}$ to $0.75 \mathrm{~mol} / \mathrm{L}$. Maximum surface area of $75.28 \mathrm{~m}^{2} / \mathrm{g}$ was obtained using $0.75 \mathrm{~mol} / \mathrm{L}$ of $\mathrm{H}_{2} \mathrm{SO}_{4}$ as shown in Fig. 1. This increase in surface area is attributed to the removal of impurities, replacement of exchangeable cations $\left(\mathrm{K}^{+}, \mathrm{Na}^{+}, \mathrm{Ca}^{2+}\right)$ with hydrogen ions and leaching of $\mathrm{Al}^{3+}, \mathrm{Fe}^{3+}$ and $\mathrm{Mg}^{2+}$ from the octahedral and tetrahedral sites in bentonite which exposes the edges of platelets (Tsai et al., 2007; Hall et al., 1966). It was observed that the surface area decreased with further increase in acid concentration beyond $0.75 \mathrm{~mol} / \mathrm{L}$. The decrease in surface area at higher acid concentrations is attributed to the deeper penetration of acid into the voids and excessive leaching of $\mathrm{Al}^{3+}, \mathrm{Fe}^{3+}$ and $\mathrm{Mg}^{2+}$, resulting in the collapse of layered structure and close packing of particles (Korichi et al., 2009). The decrease in the surface area with further increase in concentration 
beyond $0.75 \mathrm{~mol} / \mathrm{L} \mathrm{H}_{2} \mathrm{SO}_{4}$ could be attributed to the deeper penetration of the acid into the voids and excessive leaching of $\mathrm{Al}^{3+}, \mathrm{Fe}^{3+}$, and $\mathrm{Mg}^{2+}$, resulting in the collapse of the crystalline structure (Pesquera et al., 1992). The surface area of the AA activated samples is shown in Fig. 1.

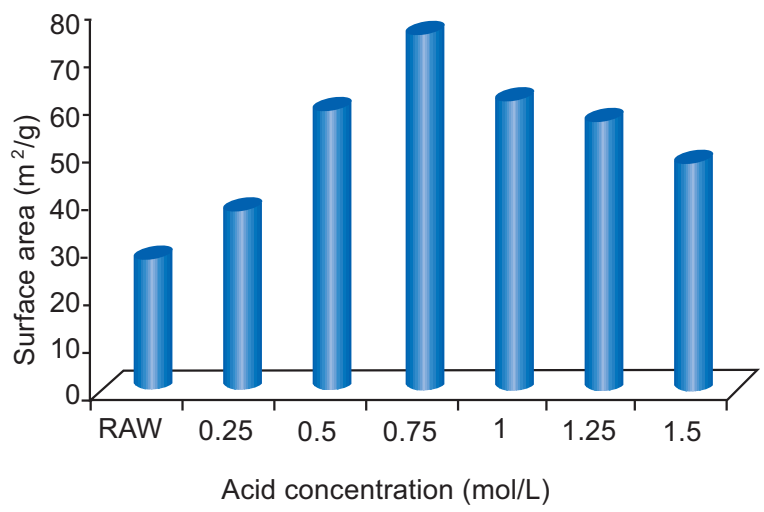

Fig. 1. Surface area of bentonite samples modified by acid activation at different concentrations.

Results of the thermally activated samples reveal that surface area increased with an increase in the temperature up to $300{ }^{\circ} \mathrm{C}$ and then gradually decreased beyond $300^{\circ} \mathrm{C}$. The increase in surface area with increasing temperature is due to the removal of adsorbed and hydrated water and other impurities attached to the surface of raw bentonite. Excessive heating may lead to irreversible collapse of structure therefore, thermal activation of bentonite has to be carried out in a particular range of temperature. The decrease in surface area with increasing temperature beyond $300{ }^{\circ} \mathrm{C}$ is attributed to the collapse of interlayer spaces (Beragaya et al., 2006). This collapse of interlayer spaces brings particles to one another and as a result surface area decreases (Chorom et al., 2004). More than 50\% increase in surface area was observed at $300{ }^{\circ} \mathrm{C}\left(51.75 \mathrm{~m}^{2} / \mathrm{g}\right)$ /compared to raw bentonite $\left(26.43 \mathrm{~m}^{2} / \mathrm{g}\right)$. Similar results have been reported by Onal and Sarikaya (2007). The surface area for all the TA samples is shown in Fig. 2.

The surface properties of acid activated bentonite can be improved further, if acid activation is followed by thermal activation (Beragaya et al., 2006). The acid activated samples were thermally activated at $300{ }^{\circ} \mathrm{C}$. The surface area of the bentonite modified by AA was recorded as $75.28 \mathrm{~m}^{2} / \mathrm{g}(0.75 \mathrm{~mol} / \mathrm{L})$. The surface area was observed to increase to $89.64 \mathrm{~m}^{2} / \mathrm{g}$ when acid activation was followed by thermal activation as shown in Fig. 3.

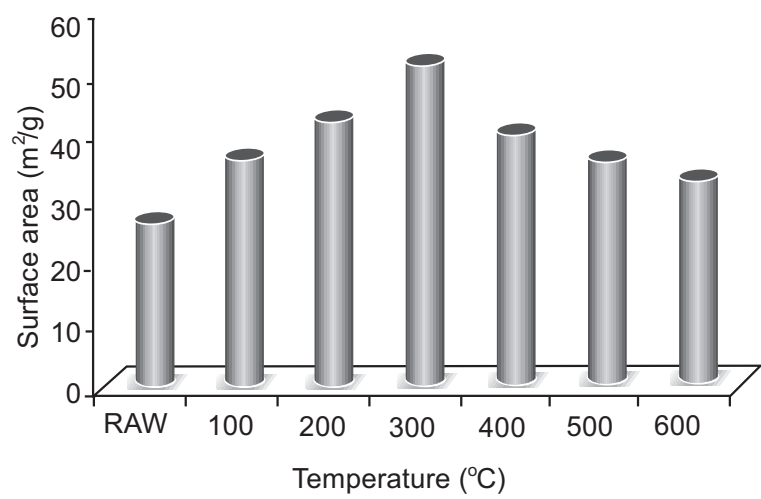

Fig. 2. Surface area of bentonite samples modified by thermal activation at different temperatures.

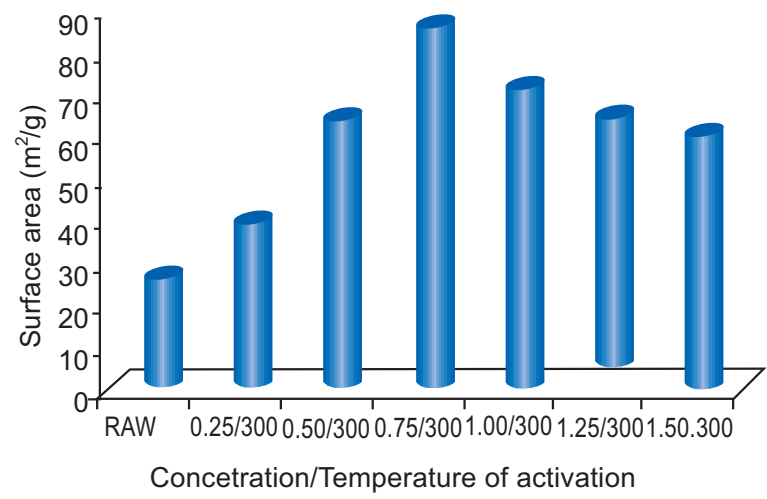

Fig. 3. Surface area of bentonite samples modified by acid/thermal activation.

Effects of process parameters. Effect of initial dye concentration. The effect of initial dye concentration on the adsorption performance of raw bentonite and bentonite modified by acid, thermal and combined acid/thermal activation was investigated over a concentration range of $50 \mathrm{mg} / \mathrm{L}-500 \mathrm{mg} / \mathrm{L}$. The results of the experimental data are given in Fig. 4. The results show that bentonite modified by ATA gave the maximum adsorption of $44.82 \mathrm{mg} / \mathrm{g}$ for $500 \mathrm{mg} / \mathrm{L}$ of initial dye concentration. The adsorption capacity by the raw and modified bentonite follows the order: ATA $>$ AA $>$ TA $>$ RB. The increase in adsorption with the increase in dye concentration is due to the driving force that initial concentration provides to overcome the mass transfer resistance between the aqueous and solid phases. The adsorption rate was high at early adsorption period due to availability of large number of vacant site which increased the concentration gradient between the adsorbate in the solution and adsorbate on the adsorbent surface (Zohra et al., 2008). The steady increase in the adsorption with the increase in initial dye concentration indicates that the adsorbents have very high potential for the removal of Congo red. 


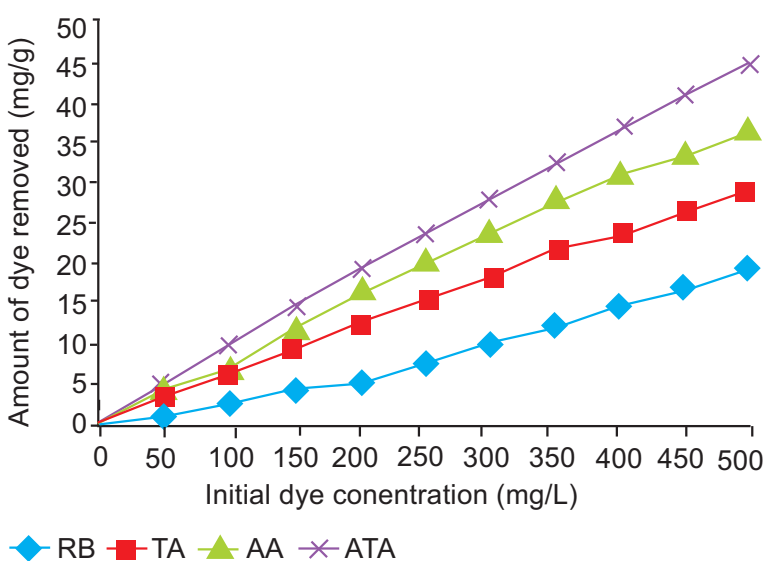

Fig. 4. Effect of initial dye concentration on the amount of dye removed.

Effect of temperature. The results of the adsorption of Congo red on raw and modified bentonite at different temperatures from 30 to $80{ }^{\circ} \mathrm{C}$ are shown in Fig. 5. The figure shows that the adsorption capacity increased when the temperature was increased. The percentage adsorption increased from 48.30 to $85.80 \% ; 61.40$ to $94.60 \% ; 70.50$ to $94.70 \%$; and 87.60 to $98.80 \%$ for the bentonite samples RB, TA, AA, and ATA, respectively, at the initial concentration of $500 \mathrm{mg} / \mathrm{L}$ when the temperature was increased from 30 to $80^{\circ} \mathrm{C}$. The increase in adsorption capacity was due to the creation of active sites at higher temperature.

Effect of contact time. The effect of contact time on the removal of Congo red by raw and modified bentonite at initial concentrations of CR $50 \mathrm{mg} / \mathrm{L}$ is shown in Fig. 6. The contact time was varied from 2 to $24 \mathrm{~h}$ at constant temperature. The time plot shows that, the removal of adsorbate is rapid in early stages, for the raw and bentonite modified by TA and AA, but it gradually slows down until

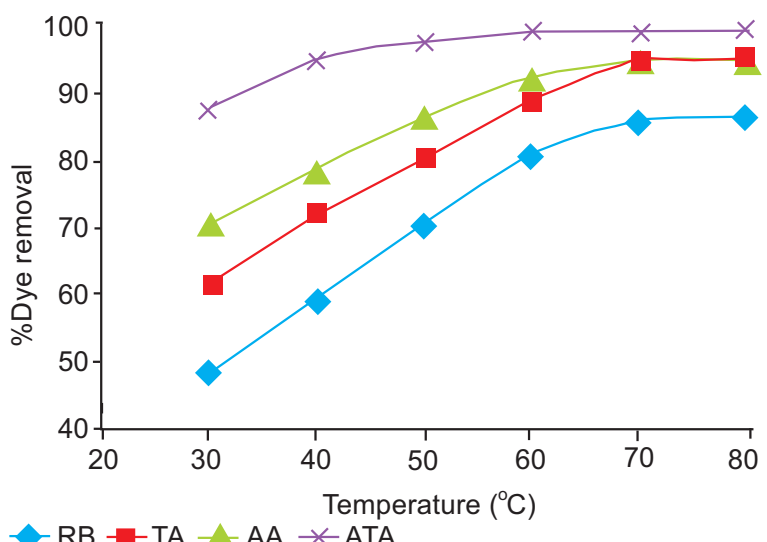

Fig. 5. Effect of temperature on the percentage dye removed.

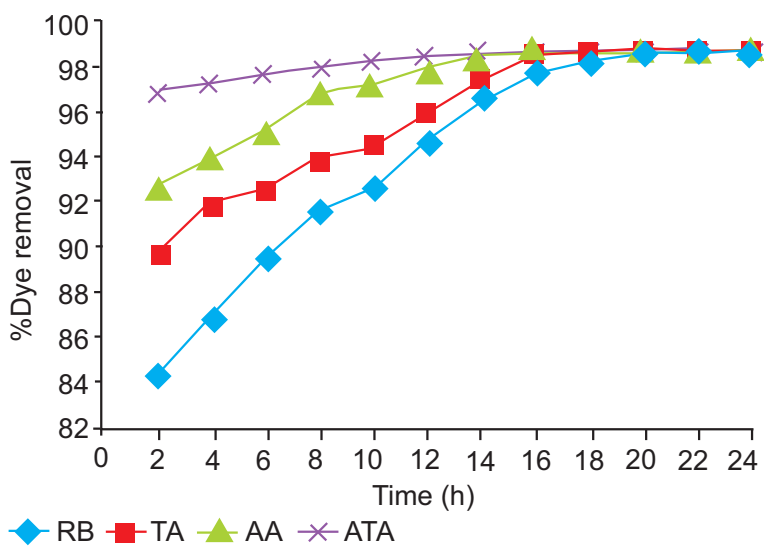

Fig. 6. Effect of contact time on the percentage dye removed.

it reaches the equilibrium. This is due to the fact that a large number of vacant surface sites are available for adsorption during the initial stage, and after a lapse of time the remaining vacant surface sites are difficult to be occupied due to repulsive forces between the solute molecules on the solid surface and in bulk phase (Ahmad et al., 2009). The equilibrium was attained after shaking for $14 \mathrm{~h}$ for AA, $16 \mathrm{~h}$ for TA and $18 \mathrm{~h}$ for RB. The effect of contact time was observed to be insignificant for the ATA modified bentonite sample, for sorption equilibrium was achieved after $6 \mathrm{~h}$ of shaking. Once equilibrium was attained, the percentage sorption of CR did not change with further increases of time.

Effect of adsorbent dosage. The results of the effect of adsorbent dosage on the adsorption efficiency of the raw bentonite and those modified by thermal, acid, and combined acid/thermal activation are shown in Fig. 7. It was observed that, the Congo red removal by the

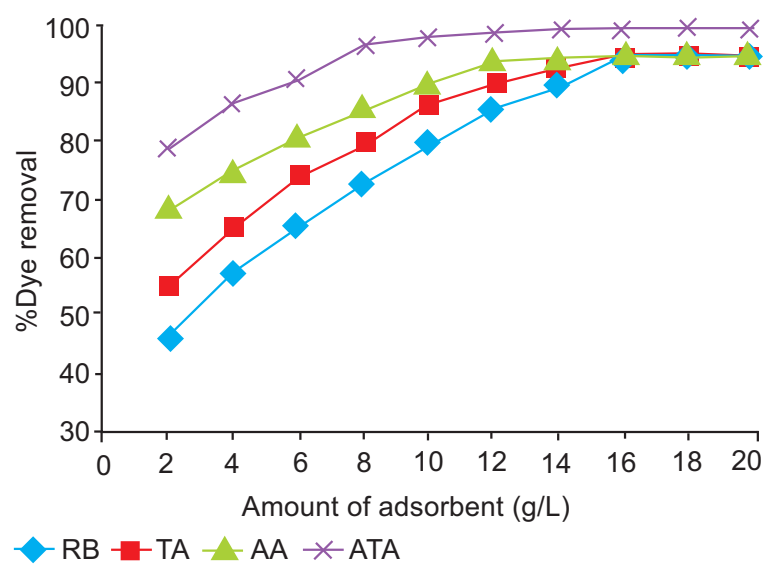

Fig. 7. Effect of adsorbent dosage on the percentage dye removed. 
ATA, bentonite increased as the adsorbent dosage increased gradually up to $10 \mathrm{~g} / \mathrm{L}$ of clay dosage. A further increase in bentonite dosage beyond $10 \mathrm{~g} / \mathrm{L}$ had no significant improvement in the dye removal due to attainment of equilibrium between the adsorbent and adsorbate (Chaari et al., 2008). Equilibrium was achieved using the bentonite modified by AA and TA at clay dosage of $14 \mathrm{~g} / \mathrm{L}$, while the RB attained equilibrium at clay dosage of $16 / \mathrm{g} \mathrm{L}$. The increase in adsorption capacity of the raw and modified bentonite with increase in adsorbent dosage is attributed to increase in surface area of micro-pores and the increase in availability of vacant adsorption sites (Khenifi et al., 2007).

Effect of $\mathbf{p H}$. In this study, the effect of $\mathrm{pH}$ on the sorption performance of the adsorbents was studied in the range of 1-11 and the results are shown in Fig. 8. The results in Fig. 8 show that the maximum adsorption for the ATA sample was observed at $\mathrm{pH} 7$ and above. At $\mathrm{pH} 7$, the $\mathrm{CR}$ removal percentage was $97.8 \%$ and amount adsorbed was $31.77 \mathrm{mg} / \mathrm{g}$ which was increased to $98.9 \%$ and $39.84 \mathrm{mg} / \mathrm{g}$ at $\mathrm{pH} 9$ and then to $99.8 \%$ and $42.12 \mathrm{mg} / \mathrm{g}$ when the $\mathrm{pH}$ rose to 10. Maximum adsorption for samples RB, TA, and AA was observed at $\mathrm{pH}$ above 9, 9, and 8, respectively, with CR removal percentage of $95.4 \%, 97.3 \%$, and $98.6 \%$, respectively. Lower adsorption of $\mathrm{CR}$ at acidic $\mathrm{pH}$ is probably due to the presence of excess $\mathrm{H}+$ ions competing with the cation groups on the dye for adsorption sites. At higher $\mathrm{pH}$, the surface of the clay adsorbents particles may get negatively charged, which enhances the adsorption of positively charged dye cations through electrostatic forces of attraction.

Adsorption isotherm. Equilibrium study on adsorption provides information on the capacity of the adsorbent. An adsorption isotherm is characterised by certain

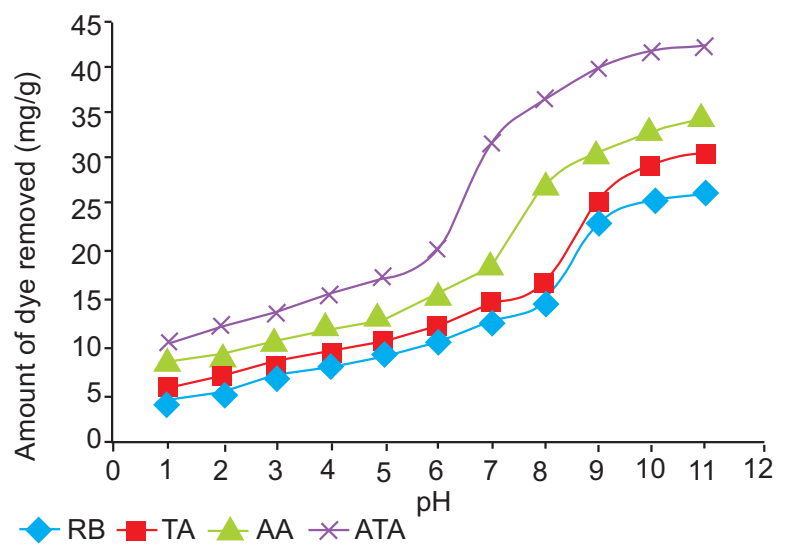

Fig. 8. Effect of $\mathrm{pH}$ on the amount of dye removed. constant values, which express the surface properties and affinity of the adsorbent, and could also be used to compare the adsorptive capacities of the adsorbent for different pollutants. The adsorption isotherms of $\mathrm{CR}$ on raw and activated bentonite were studied and the equilibrium data was analysed using Langmuir, Freundlich, and Dubinin- Radushkevich models.

Langmuir isotherm. The Langmuir isotherm model is based on the fact that uptake of dye molecules occurs on a homogeneous surface by monolayer adsorption with no interaction between adsorbed molecules, with homogeneous binding sites, equivalent sorption energies, and no interaction between adsorbed species. The model is given by the following linear equation:

$$
\frac{\mathrm{C}_{\mathrm{e}}}{\mathrm{q}_{\mathrm{e}}}=\frac{1}{\mathrm{q}_{\mathrm{m}} \mathrm{K}_{\mathrm{L}}}+\frac{\mathrm{C}_{\mathrm{e}}}{\mathrm{q}_{\mathrm{m}}}
$$

Where:

$\mathrm{C}_{\mathrm{e}}$ is the equilibrium concentration $(\mathrm{mg} / \mathrm{L}) ; \mathrm{q}_{\mathrm{e}}$ is the amount of dye ion adsorbed $(\mathrm{mg} / \mathrm{g}) ; \mathrm{q}_{\mathrm{m}}$ is the Langmuir constant for adsorption capacity $(\mathrm{mg} / \mathrm{g}) ; \mathrm{K}_{\mathrm{L}}$ is sorption equilibrium constant (L/g).

The values of $q_{m}$ and $K_{L}$ were evaluated from the slope and intercept of the plot of $\mathrm{C}_{\mathrm{e}} / \mathrm{q}_{\mathrm{e}}$ versus $\mathrm{C}_{\mathrm{e}}$ as shown in Fig. 9 (Aluyor et al., 2009; Langmuir, 1916) and are given in Table 4.

A further analysis of the Langmuir equation can be made on the basis of a dimensionless equilibrium parameter, $\mathrm{R}_{\mathrm{L}}$ (Hall et al., 1966) also known as the separation factor, and has been suggested to express the essential characteristics of the Langmuir isotherm (Sumanjit et al., 2008; Arivoli, 2007; Hema and Malik,

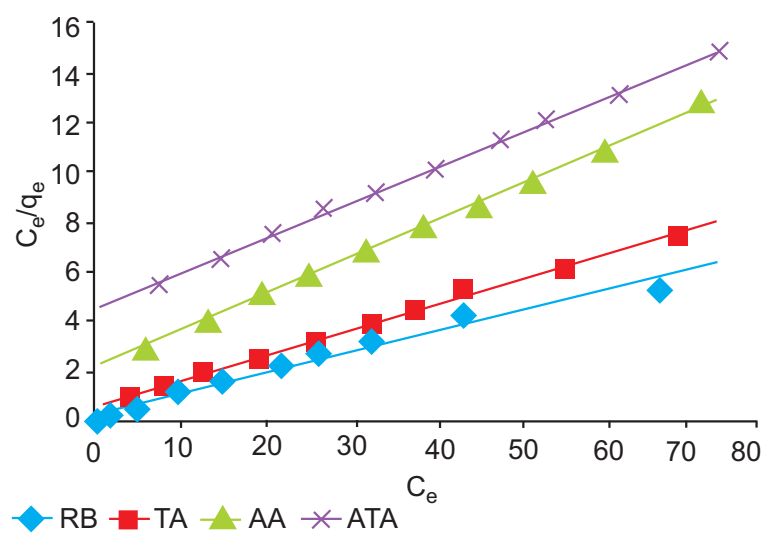

Fig. 9. Langmuir isotherm plot. 
Table 4. Langmuir, Freundlich, and Dubinin-Radushkevich isotherm parameters for adsorption of CR on to activated Nkalagu bentonite

\begin{tabular}{llllll}
\hline \hline Isotherm models & Parameters & \multicolumn{3}{c}{ Clay samples } \\
\cline { 3 - 6 } & & ATA & AA & TA & $\mathrm{RB}$ \\
\hline Langmuir & $\mathrm{q}_{\mathrm{m}}(\mathrm{mg} / \mathrm{g})$ & 12.35 & 10.2 & 7.09 & 7.35 \\
& $\mathrm{~K}_{\mathrm{L}}(\mathrm{L} / \mathrm{mg})$ & 0.289 & 0.166 & 0.064 & 0.03 \\
& $\mathrm{R}^{2}$ & 0.998 & 0.997 & 0.998 & 0.997 \\
Freundlich & $\mathrm{K}_{\mathrm{f}}(\mathrm{mg} / \mathrm{g})$ & 5.929 & 3.467 & 1.033 & 0.504 \\
& $\mathrm{n}$ & 6.098 & 3.968 & 2.358 & 1.808 \\
& $\mathrm{R}^{2}$ & 0.979 & 0.954 & 0.959 & 0.985 \\
Dubinin-Radushkevich & $\mathrm{X}_{\mathrm{m}}(\mathrm{mg} / \mathrm{g})$ & 5.948 & 3.469 & 1.214 & 0.503 \\
& $\beta\left(10^{-5}\right)$ & -6.00 & -7.00 & -13.3 & -19.4 \\
& $\mathrm{E}(\mathrm{kJ} / \mathrm{mol})$ & -9.129 & -7.454 & -6.115 & -5.077 \\
& $\mathrm{R}^{2}$ & 0.976 & 0.954 & 0.976 & 0.985 \\
\hline \hline
\end{tabular}

$\mathrm{ATA}=\mathrm{acid} /$ thermal activation; $\mathrm{AA}=$ acid activation; $\mathrm{TA}=$ thermal activation; $\mathrm{RB}=$ raw bentonite.

2004). It is a measure of the favourability of the adsorption process (Mittal et al., 2007). $\mathrm{R}_{\mathrm{L}}$ is given by

$\mathrm{R}_{\mathrm{L}}=\frac{1}{\left(1+\mathrm{C}_{\mathrm{L}} \mathrm{C}_{\mathrm{e}}\right)}$

The value of $\mathrm{R}_{\mathrm{L}}$ lies between 0 and 1 for favourable adsorption, while $\mathrm{R}_{\mathrm{L}}>1$ represents unfavourable adsorption, and $\mathrm{R}_{\mathrm{L}}=1$ represents linear adsorption while the adsorption process is irreversible if $R_{L}=0$. Results of $R_{L}$ calculated from this study (shown in Fig. 10) lies between 0.048 and 0.924 and this is consistent with the requirement for favourable adsorption of CR on RB, TA, AA, and ATA.

Freundlich isotherm. Freundlich isotherm assumes that the uptake of ions occur on a heterogeneous surface by multilayer adsorption and that the amount of adsorbate adsorbed increases infinitely with an increase in concentration. It is a most popular model for a single solute system, based on the distribution of solute between the solid phase and

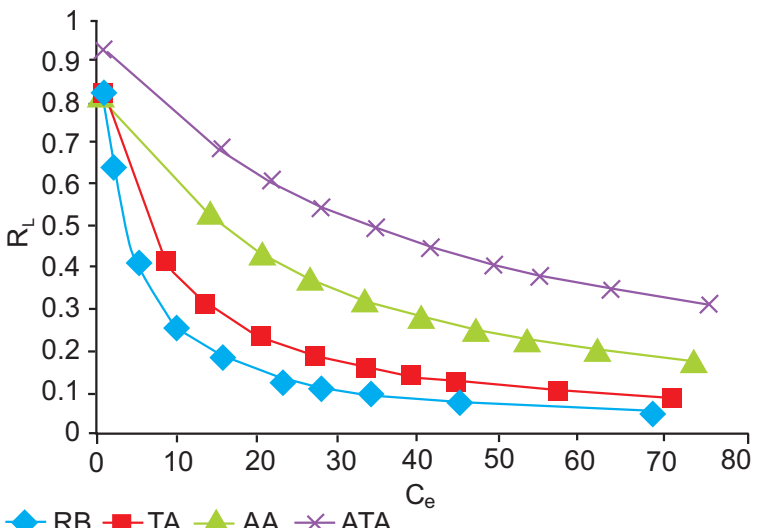

Fig. 10. Plot of separation factor, $R_{L}$ versus $C_{e}$. aqueous phase at equilibrium (Sivakumar and Palanisaw, 2009). The Freundlich equation is expressed as:

$q_{e}=K_{f} C_{e}^{\frac{1}{n}}$

Where:

$\mathrm{K}_{\mathrm{f}}$ is the measure of adsorption capacity and $\mathrm{n}$ is the adsorption intensity. Linear form of Freundlich equation (Babel and Kurniawan, 2004) is:

$\log \mathrm{q}_{\mathrm{e}}=\log \mathrm{K}_{\mathrm{f}}+\frac{1}{\mathrm{n}} \log \mathrm{C}_{\mathrm{e}}$

Where:

$\mathrm{q}_{\mathrm{e}}$ is the amount adsorbed ( $\left.\mathrm{mg} / \mathrm{g}\right), \mathrm{C}_{\mathrm{e}}$ is the equilibrium concentration of adsorbate $(\mathrm{mg} / \mathrm{L})$ and $\mathrm{K}_{\mathrm{f}}$ and $\mathrm{n}$ are the Freundlich constants related to the adsorption capacity and adsorption intensity, respectively. A plot of $\log \mathrm{q}_{\mathrm{e}}$ $v s \log \mathrm{C}_{\mathrm{e}}$ (Fig. 11) gives a linear trace with a slope of $1 / \mathrm{n}$ and intercept of $\log \mathrm{K}_{\mathrm{f}}$ and the results are also given in Table 4. When $1 / \mathrm{n}>1.0$, the change in adsorbed metal ion concentration is greater than the change in the metal ion concentration in solution.

Dubinin-Radushkevich isotherm. The D-R equation has been widely used to explain energetic heterogeneity of solid at low coverage as monolayer regions in micropores. The equation is given by

In $\mathrm{q}_{\mathrm{e}}=$ In $\mathrm{X}_{\mathrm{m}}-\beta \varepsilon^{2}$

Where:

$\beta$ is the activity coefficient related to mean adsorption 


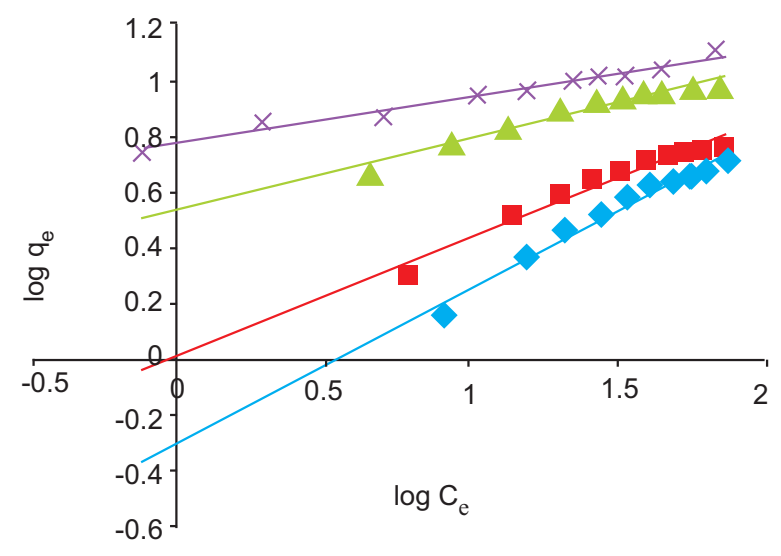

$R B \rightarrow T A-A A * A T A$

Fig. 11. Freundlich isotherm plot.

energy, $\mathrm{X}_{\mathrm{m}}$ the maximum of adsorption capacity and $\varepsilon$ is the Polangi potential, which is equal to

$\varepsilon=\operatorname{RT} \operatorname{In}\left(\frac{1}{\mathrm{C}_{\mathrm{e}}}\right)$

Where:

$\mathrm{R}$ and $\mathrm{T}$ are the gas constant $(\mathrm{kJ} / \mathrm{mol} / \mathrm{K})$ and temperature (K), respectively.

The adsorption energy E expressed as:

$E=-\frac{1}{(-2 \beta)^{0.5}}$

reveals the nature of adsorption. If the value of adsorption energy $\mathrm{E}$ ranged between -1 and $-8 \mathrm{~kJ} / \mathrm{mol}$, adsorption process is physical, and if the value of $\mathrm{E}$ ranged between -9 and $-16 \mathrm{~kJ} / \mathrm{mol}$, it is chemical adsorption. The parameters of the D-R equation were calculated from the slope and intercept of the linear plot of $\ln$ qe versus $\varepsilon^{2}$ (Fig. 12) and are given in Table 4.

The adsorption energy E value obtained $-9.13 \mathrm{~kJ} / \mathrm{mol}$ showed that the adsorption of CR on to activated Nkalagu bentonite is a chemical process.

The good fit of the experimental data and the determination coefficient closer to unity indicated the applicability of the Langmuir isotherm model to describe the adsorption of $\mathrm{CR}$ on to raw and activated Nkalagu bentonite.

Adsorption kinetics. The effect of contact time on the adsorption of Congo red on activated Nkalagu bentonite has been studied and the results show that adsorption increased with increase in contact time. The experimental data were examined by pseudo-first-order, pseudo-second-

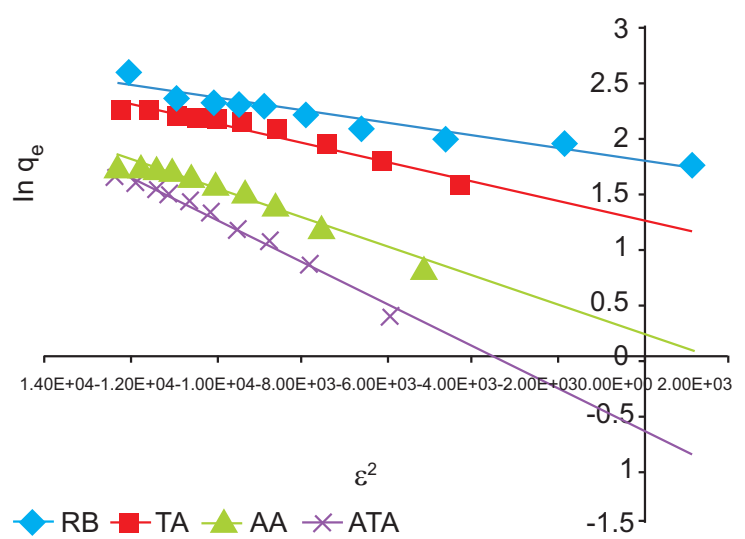

Fig. 12. Dubinin-Radushkevich isotherm plot.

order, and intra-particle diffusion kinetic equations to understand the dynamics and mechanism of the adsorption process. A simple pseudo-first order equation was used and it is given by

$\frac{\mathrm{dq}_{\mathrm{t}}}{\mathrm{d}_{\mathrm{t}}}=\mathrm{k}_{1}\left(\mathrm{q}_{\mathrm{e}}-\mathrm{q}_{\mathrm{t}}\right)$

Where:

$\mathrm{q}_{\mathrm{e}}$ and $\mathrm{q}_{\mathrm{t}}$ are the amount of $\mathrm{CR}$ adsorbed at equilibrium and at time $\mathrm{t}(\mathrm{min})$, respectively, and $\mathrm{k}_{1}$ is the rate constant of the pseudo-first order adsorption process (Ozturk and Kavak, 2005; Ho and Mckay, 1999). The linear form of the equation is given as:

$\log \left(\mathrm{q}_{\mathrm{e}}-\mathrm{q}_{\mathrm{t}}\right)=\log \mathrm{q}_{\mathrm{e}}-\frac{\mathrm{k}_{1}}{2.303} \mathrm{t}$

The values of $\mathrm{k}_{1}$ and $\mathrm{q}_{\mathrm{e}}$ were calculated from the slope and intercept of the linear plot of $\log \left(\mathrm{q}_{\mathrm{e}}-\mathrm{q}_{\mathrm{et}}\right)$ versus $\mathrm{t}$ (Fig. 13) and are given in Table 5.

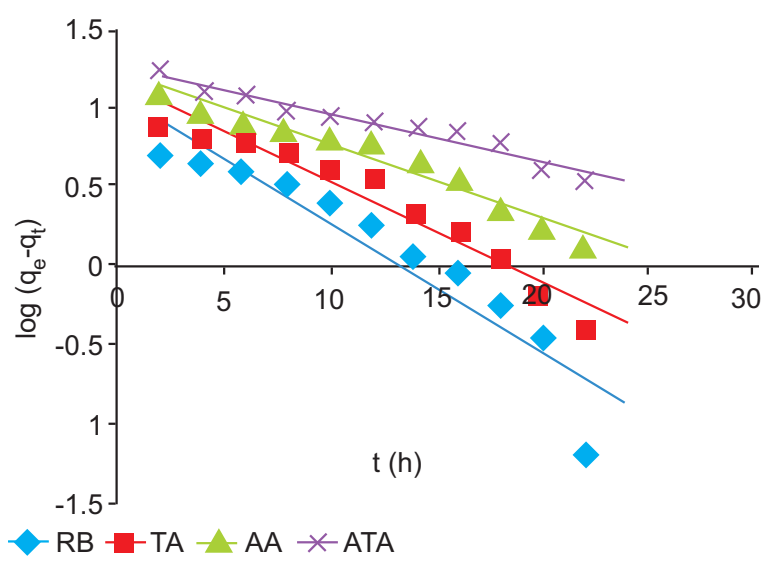

Fig. 13. Pseudo-first-order reaction kinetics for the adsorption of $\mathrm{CR}$ onto activated Nkalagu bentonite. 
Table 5. Parameters of the Pseudo-first-order, Pseudo-second-order, Elovich, and Intra-particle kinetic models together with their regression coefficients

\begin{tabular}{llllll}
\hline \hline Kinetic models & Parameters & \multicolumn{3}{c}{ Clay samples } \\
\cline { 4 - 6 } & & ATA & AA & TA & RB \\
\hline Pseudo-first-order & $\mathrm{k}_{1}\left(\mathrm{~min}^{-1}\right)$ & 0.1911 & 0.1451 & 0.1059 & 0.0691 \\
& $\mathrm{q}_{\mathrm{e}}(\mathrm{mg} / \mathrm{g})$ & 12.94 & 14.72 & 17.26 & 18.45 \\
& $\mathrm{R}^{2}$ & 0.875 & 0.937 & 0.959 & 0.952 \\
Pseudo-second-order & $\mathrm{k}_{2}(\mathrm{~g} / \mathrm{mg}$ min $)$ & 0.0218 & 0.0074 & 0.0063 & 0.0067 \\
& $\mathrm{q}_{\mathrm{e}}(\mathrm{mg} / \mathrm{g})$ & 11.49 & 12.82 & 12.2 & 10.87 \\
& $\mathrm{R}^{2}$ & 0.998 & 0.996 & 0.997 & 0.997 \\
Elovich & $\beta$ & 0.413 & 0.395 & 0.401 & 0.409 \\
& $\alpha(\mathrm{mg} / \mathrm{g}$ min $)$ & 5.92 & 3 & 2.43 & 1.35 \\
Intra-particle & $\mathrm{R}^{2}$ & 0.964 & 0.939 & 0.908 & 0.926 \\
& $\mathrm{~K}_{\mathrm{p}}(\mathrm{mg} / \mathrm{g}$ min & & & 1.5 \\
& $\mathrm{C}$ & 1.677 & 1.782 & 1.773 & -1.639 \\
\hline \hline
\end{tabular}

$\mathrm{ATA}=\mathrm{acid} /$ thermal activation; $\mathrm{AA}=$ acid activation; $\mathrm{TA}=$ thermal activation; $\mathrm{RB}=$ raw bentonite.

The corresponding pseudo-second order rate equation (Ho and Mckay, 1998) is given as:

$\frac{\mathrm{t}}{\mathrm{q}_{\mathrm{t}}}=\frac{1}{\mathrm{k}_{2} \mathrm{q}_{\mathrm{e}}^{2}}+\frac{\mathrm{t}}{\mathrm{q}_{\mathrm{e}}}$

Where:

$\mathrm{k}_{2}$ is the rate constant for the pseudo-second order adsorption process $(\mathrm{g} / \mathrm{mg} / \mathrm{min})$. The slope and intercept of the plot of $t / q_{t}$ versus $t$ (Fig. 14) were used to calculate the values of $\mathrm{q}_{\mathrm{e}}$ and $\mathrm{k}_{2}$ as presented in Table 5. The value of the regression coefficient calculated from the plot of the second-order kinetic plot shows that it best fitted the experimental data and can be used to describe the adsorption of CR on to activated Nkalagu bentonite.

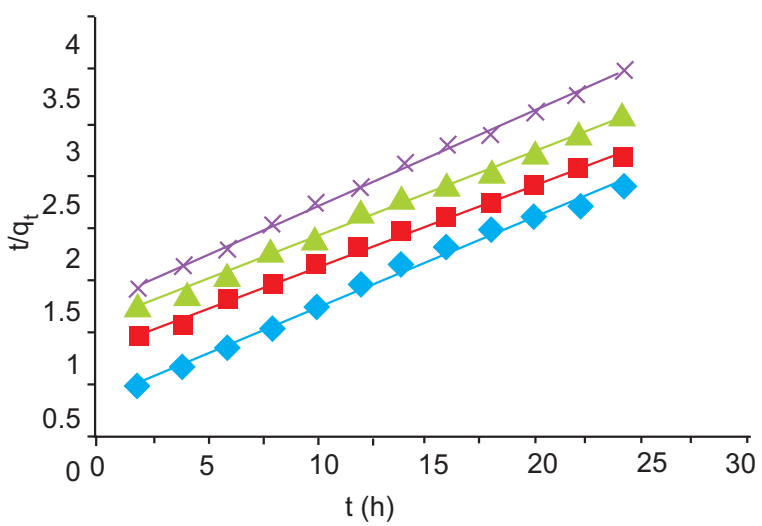

$\mathrm{RB}-\mathrm{TA} \rightarrow \mathrm{AA} * \mathrm{ATA}$

Fig. 14. Pseudo-second-order kinetic plot for $C R$ adsorption onto activated Nkalagu bentonite.
The Elovich model is presented by the following equation:

$\mathrm{q}_{\mathrm{t}}=\frac{1}{\beta} \operatorname{In} \alpha \beta+\frac{1}{\beta}$ In $\mathrm{t}$

Where:

$\alpha$ is the initial adsorption rate $(\mathrm{mg} / \mathrm{g} / \mathrm{min})$ and $\beta$ is the desorption constant $(\mathrm{g} / \mathrm{mg})$. The slope and intercept of the plot of $\mathrm{q}_{\mathrm{t}}$ versus $\ln \mathrm{t}$ were used to calculate the values of the constants $\alpha$ and $\beta$ as shown in Table 5 . The value of the determination coefficient obtained from the linear plot of Elovich (Fig. 15) models are not high $\left(\mathrm{R}^{2}<0.9321\right)$, suggesting that the applicability of this model to describe the adsorption process of CR on to activated Nkalagu bentonite is not feasible.

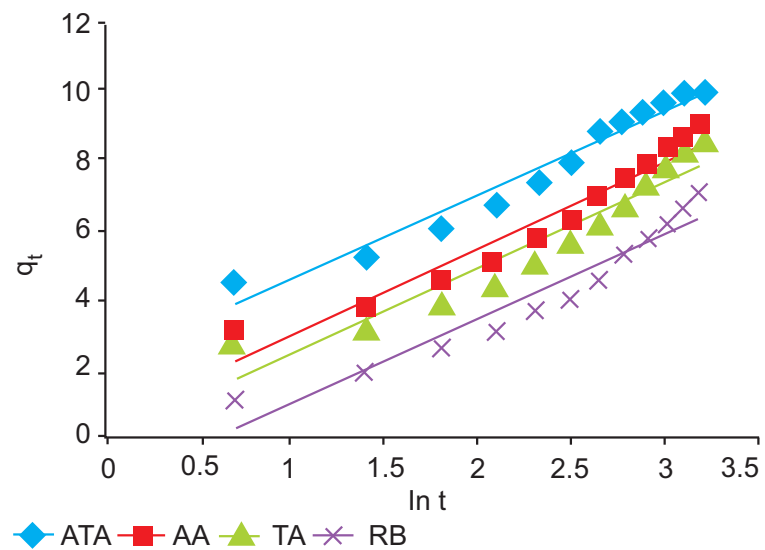

Fig. 15. Elovich kinetic model plot for $\mathrm{CR}$ adsorption onto activated Nkalagu bentonite. 
Intra-particle diffusion study. The adsorption mechanism of adsorbate on to adsorbent follows three steps: (1) transport of adsorbate from the boundary film to the external surface of the adsorbate; (2) adsorption at a site on the surface; (3) intra-particle diffusion of the adsorbate molecules to an adsorption site by a pore diffusion process. The slowest of the three steps controls the overall rate of the process. The possibility of intra-particle diffusion was explored by using an intra-particle diffusion model. The intra-particle diffusion varies with square root of time and is given (Karthikeyan et al., 2005; Ho and Mckay, 1998) as:

$\mathrm{q}_{\mathrm{t}}=\mathrm{k}_{\mathrm{id}} \mathrm{t}^{\frac{1}{2}}+\mathrm{C}_{\mathrm{i}}$

Where:

qt is the amount adsorbed at time $t, t^{1 / 2}$ is the square root of the time, $\mathrm{k}_{\mathrm{id}}$ is the intra-particle diffusion rate constant $\left(\mathrm{mg} / \mathrm{g} \mathrm{min}{ }^{1 / 2}\right)$, and $\mathrm{C}_{\mathrm{i}}$ is the intercept at stage $\mathrm{i}$ and is related to the thickness of the boundary layer. Large $C_{i}$ represents the greater effect of the boundary layer on molecule diffusion. The intra-particle diffusion rate constant was determined from the slope of the linear gradients of the plot $\mathrm{q}_{\mathrm{t}}$ versus $\mathrm{t}^{1 / 2}$ as shown in Fig. 16 and their values are presented in Table 5. The intra-particle diffusion process is controlled by the diffusion of ions within the adsorbent.

The mechanism of solute transfer to the solid includes diffusion through the fluid film around the adsorbent particle and diffusion through the pores to the internal adsorption sites. Initially the concentration gradient between the film and the solid surface is large, hence the transfer of solute onto the solid surface is faster. As time increases, intra-particle diffusion becomes

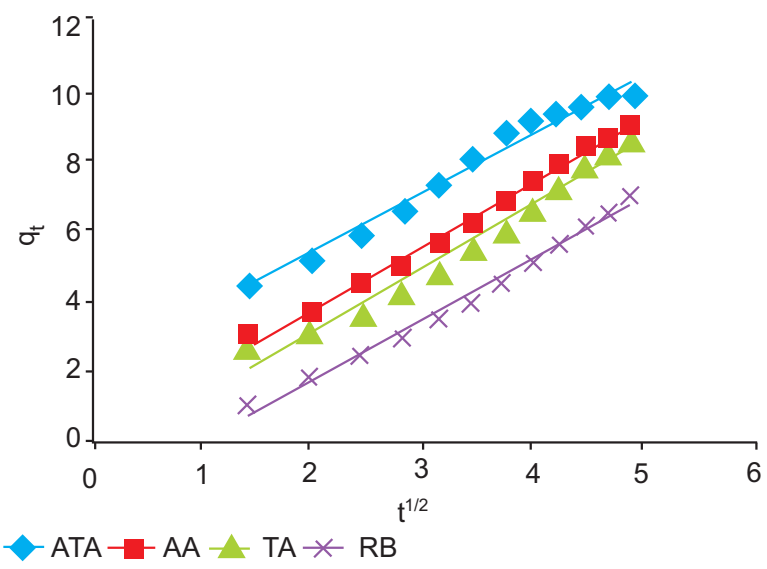

Fig. 16. Intra-particle diffusion plot for $C R$ adsorption onto activated Nkalagu bentonite. predominant. Hence, solute takes more time to transfer from solid surface to internal adsorption sites through the pores (Babu and Gupta, 2008).

Thermodynamic studies. The thermodynamic parameters such as free energy $\left(\Delta \mathrm{G}^{\circ}\right)(\mathrm{kJ} / \mathrm{mol})$, enthalpy $\left(\Delta \mathrm{H}^{\circ}\right)(\mathrm{kJ} / \mathrm{mol})$ and entropy $\left(\Delta \mathrm{S}^{\circ}\right)(\mathrm{J} / \mathrm{mol})$ for adsorption of Congo red on raw and modified bentonite were determined. The $\Delta \mathrm{H}^{\circ}$ and $\Delta \mathrm{S}^{\circ}$ were obtained from the slope and intercept of the Van't Hoff's plot of $\ln \mathrm{K}_{\mathrm{c}}$ vs. 1/T as shown in Fig. 17. Positive value of $\Delta \mathrm{H}^{\circ}$ indicates that, the adsorption process is endothermic. The negative values of $\Delta \mathrm{G}^{\circ}$ (Table 6) reflect the feasibility of the process and the values become more negative with increase in temperature as well as it shows that, the adsorption is highly favourable and spontaneous. The positive values of standard $\Delta \mathrm{S}^{\circ}$ entropy (Table 6) show the increased disorder and randomness at the solid solution interface of dye ion with modified bentonite. The enhancement of adsorption capacity of the modified bentonite at higher temperatures was attributed to the enlargement of pore size and activation of the adsorbent surface. The enrichment in the adsorption capacity may be due to the chemical interaction between adsorbate

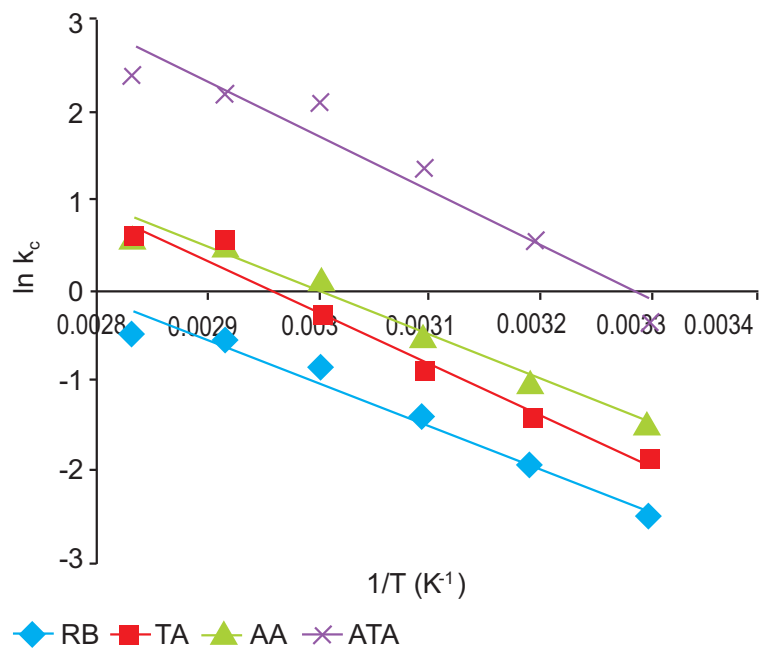

Fig. 17. Plot of $\ln \mathrm{kc}$ versus inverse of temperature.

and adsorbent, creation of some new adsorption sites or the increased rate of intra-particle diffusion of dye ions into the pores of the adsorbent at higher temperatures (Karthikeyan et al., 2005).

\section{Conclusion}

In this study, bentonite from Nkalagu was successfully modified thermally, chemically, and simultaneous chemical/thermal treatment. It was observed that the physicochemical properties such as surface area, cation 
Table 6. Thermodynamic parameters for the removal of CR from aqueous solution

\begin{tabular}{lllllllll}
\hline \hline Clay samples & $\begin{array}{l}\Delta \mathrm{H}^{\circ} \\
(\mathrm{kJ} / \mathrm{mol})\end{array}$ & $\begin{array}{l}\Delta \mathrm{S}^{\circ} \\
(\mathrm{J} / \mathrm{mol})\end{array}$ & $303 \mathrm{~K}$ & $313 \mathrm{~K}$ & $323 \mathrm{~K}$ & $333 \mathrm{~K}$ & $343 \mathrm{~K}$ & $353 \mathrm{~K}$ \\
\hline RB & 38.693 & 107.58 & -32.56 & -33.63 & -34.71 & -35.79 & -36.86 & -37.94 \\
TA & 47.357 & 140.34 & -42.48 & -43.88 & -45.28 & -46.69 & -48.09 & -49.49 \\
AA & 39.882 & 120.06 & -36.34 & -37.54 & -38.74 & -39.94 & -41.14 & -42.34 \\
ATA & 49.726 & 163.45 & -49.48 & -51.11 & -52.75 & -54.38 & -56.01 & -57.65 \\
\hline \hline
\end{tabular}

exchange capacity, and sorption capacity were altered as a result of the modification. The removal of CR ions with an initial concentration of $100 \mathrm{mg} / \mathrm{g}$ was found to be $99.85 \%$ after shaking for $14 \mathrm{~h}$ at constant temperature of $353 \mathrm{~K}$ using the acid/thermal (ATA) treated sample. The experimental data for the adsorption process were well fitted to the Langmuir adsorption isotherm model relative to the fit of Freundlich and Dubinin-Radushkevich models. The kinetic analysis showed that adsorption of CR ions obeyed the pseudo-second-order kinetic equation. The increase in the adsorption capacity observed with increasing temperature showed that the adsorption process was chemical in nature, spontaneous and endothermic as confirmed by the evaluation of the relevant thermodynamic parameters, viz. $\Delta \mathrm{G}^{\circ}, \Delta \mathrm{H}^{\circ}$, and $\Delta \mathrm{S}^{\circ}$. Results from this study have shown that Nkalagu bentonite can be used as a low-cost, readily available, and easily prepared sorbent for the effective removal of CR from aqueous solution.

\section{References}

Ahmad, A., Rafatullah, M., Sulaiman, O., Ibrahim, M.H., Hashim, R. 2009. Scavenging behaviour of meranti sawdust in the removal of methylene blue from aqueous solution. Journal of Harzardous Materials, 170: 357-365.

Al-Asheh, S., Banat, F., Abu-Aitah, L. 2003. Adsorption of phenol using different types of activated bentonites. Separation and Purification Technology, 33: 1-10.

Aluyor, E.O., Oboh, I.O., Obahiagbon, K.O. 2009. Equilibrium sorption isotherm for lead $(\mathrm{Pb})$ ions on hydrogen peroxide modified rice hulls. International Journal of Physical Sciences, 4: 423-427.

Babel, S., Kurniawan, T.A. 2004. Cr(VI) removal from synthetic wastewater using coconut shell charcoal and commercial activated carbon modified with oxidizing agents and/or chitosan. Chemosphere, 54: 951-967.

Babu, B.V., Gupta, S. 2008. Adsorption of Cr(VI) using activated neem leaves: kinetic studies. Adsorption, 14: 85-92.

Beragaya, F., Thang, B.K., Lagaly, G. 2006. Modified clays and clay minerals. In: Handbook of Clay Science, Development in Clay Science, vol. 1, pp. 46-348, Elsevier, The Netherlands.

Bulut, E., Ozacar, M., Sengil, I.A. 2008. Equilibrium and kinetic data and process design for adsorption of Congo red on bentonite. Journal of Harzardous Materials, 154: 613-622.

Carter, D.L., Heilman, M.D., Gonzalez, C.L. 1965. Ethylene glycol mono-ethyl ether for determining surface area of silicate minerals. Soil Sciences, 100: 356-363.

Carter, D.L., Mortland, M.M., Kemper, W.D. 1964. Specific Surface. Methods of soil Analysis, Chapter 16, Agronomy, No. 9, Part 1, 456 pp., $2^{\text {nd }}$ edition, American Society of Agronomy, USA.

Chaari, I., Fakhfakh, E., Chakroun, S., Bouzid, J., Boujelben, N., Feki, M., Rocha, F., Jamoussi, F. 2008. Lead removal from aqueous solution by Tunisian smectite clay. Journal of Harzardous Materials, 156: 545-551.

Chiou, C.T., Rutherford, D.W., Manes, M. 1993. Sorption of $\mathrm{N}_{2}$ and EGME vapours on some soils, clays, and mineral oxides and determination of sample surface areas by use of sorption data. Environmental Science and Technology, 27: 15871598.

Chorom, M.S., Ho, P.Y., Li, H.Y. 2004. Adsorption of anionic dyes in acid solution using chemically cross-linked chitosan beads. Dye Pigments, 60: 69-84.

Christidis, G.E., Scott, P.W., Dunham, A.C. 1997. Acid activation and bleaching capacity of bentonites from the islands of Milos and Chios, Aegean and Greece. Applied Clay Sciences, 12: 329-347.

Damardji, B., Khalaf, H., Duclaux, L., David, B. 2009. Preparation of $\mathrm{TiO}_{2}$-pillared montmorillonite as photo catalyst. Part II. Photo catalytic degradation of a textile azo dye. Applied Clay Sciences, Doi:10.1016/j.clay.2009.04.002.

Diaz, F.R.V., De Souza Santozs, R. 2001. Studies on the acid activation of Brazilian smectite clays, 
Quimica Nova, 24: 343-353.

Hall, K.R., Eagleton, L.C., Acrivos, A., Vermeulen, T. 1966. Pore and solid diffusion kinetics in fixed bed adsorption under constant pattern conditions. Industrial \& Engineering Chemistry Fundamentals, 5: 212-223.

He, H., Frost, R.L., Bostrom, T., Yuan, P., Duong, L., Yang, D., Xi, Y., Kloprogge, T. 2006. Changes in morphology of organoclays with HDTMA surfactant loading. Applied Clay Sciences, 31: 262-271.

Hema, M., Arivoli, S. 2007. Comparative study on the adsorption kinetics and thermodynamics of dyes onto acid activated low cost carbon. International Journal of Physical Sciences, 2: 010-017.

Ho, Y.S., McKay, G. 1999. The Sorption of Lead (II) ions on peat. Water Research, 33: 578-584.

Ho, Y.S., McKay, G. 1998. Sorption of dye from aqueous solution by peat. Chemical Engineering Journal, 70: $115-124$.

Inglethorpe, S.D.J., Morgan, D.J., Highley, D.E., Bloodworth, A.J. 1993. Industrial Mineral Laboratory Manual- Bentonite, British Geological Survey Technical Report, WG/93/20, pp. 453-476.

Jagatap, N., Ramaswamy, V. 2006. Oxidation of aniline over titania pillared montmorillonite clays. Applied Clay Sciences, 33; 89-98.

Jiuhui, Q.U. 2008. Research progress of novel adsorption processes in water purification: A review. Journal of Environmental Sciences, 20: 1-13.

Jovanovic, N., Jonackovic, J. 1990. Pore structure and adsorption properties of an acid-activated bentonite. Applied Clay Sciences, 6: 59-68.

Kabra, K., Chaudhary, R., Sawhney, R.L. 2004. Treatment of hazardous organic and inorganic compounds through aqueous-phase photo-catalysis: A review. Industrial \& Engineering Chemistry Research, 43: 7683-7696.

Kara, M., Yuzer, H., Sabah, E., Celik, M.S. 2003. Adsorption of cobalt from aqueous solutions onto sepiolite. Water Research, 37: 224-232.

Karthikeyan, T., Rajgopal, S., Miranda, L.R. 2005. Chromium (VI) adsorption from aqueous solution by Hevea brasilinesis sawdust activated carbon. Journal of Harzardous Materials, 124: 192-199. Khadhraoui, M., Trabelsi, H., Ksibi, M., Bouguerra, S., Elleuch, B. 2009. Discolouration and detoxification of Congo red dye solution by means of ozone treatment for a possible water reuse. Journal of Harzardous Materials, 161: 974-981.
Khenifi, A., Bouberka, Z., Kameche, F., Derriche, Z. 2007. Adsorption study of an industrial dye by an organic clay. Adsorption, 13: 149-158.

Korichi, S., Elias, A., Mefti, A. 2009. Characterization of smectite after acid activation with microwave irradiation. Applied Clay Sciences, 42: 432-438.

Langmuir, I. 1916. The constitution and fundamental properties of solids and liquids. Journal of American Chemical Society, 38: 2221-2295.

Li, Z., Bowman, R.S. 1997. Counter ion effects on the sorption of cationic surfactant and chromate on natural clinoptilite. Environmental Science Technology, 31: 2407-2412.

Liu, P. 2007. Polymer modified clay minerals: A review. Applied Clay Science, 38: 64- 76.

Malik, P.K. 2004. Dye removal from wastewater using activated carbon developed from sawdust: Adsorption equilibrium and kinetics. Journal of Harzardous Materials, 113: 81-88.

Mittal, A., Mittal, J., Kurup, L. 2007. Utilization of hen feathers for the adsorption of indigo carmie from simulated effluents. Journal of Environmental Protection Science, 1: 92-100.

Nandi, B.K., Goswami, A., Purkait, M.K. 2009. Removal of cationic dyes from aqueous solutions by kaolin: Kinetic and equilibrium studies. Appied Clay Science, 42: 583- 590.

Onal, M., Sarikaya, Y. 2007. Preparation and characterization of acid-activated bentonite powders. Powder Technology, 172: 14-18.

Ozcan, A.S., Erdem, B., Ozcan, A. 2005. Adsorption of acid blue 193 from aqueous solutions onto BTMA activated bentonite. Colloid Surface A; Physicochemical Engineering Aspects, 266: 73-81.

Ozturk, N., Kavak, D. 2005. Adsorption of boron from aqueous solutions using fly ash: Batch and column studies. Journal of Harzardous Materials, 127, 81-88.

Paiva, de L.B., Morales, A.R., Diaz, F.R.V. 2008. Organoclays: Properties, preparation and applications. Applied Clay Science, 42: 8-24.

Pandit, P., Basu, S. 2002. Removal of organic dyes from water by liquid-liquid extraction using reverse micelles. Journal of Colloid Interface Science, 245: 208-214.

Pesquera, C., Gonzalez, F., Benito, I., Blanco, C., Mendioroz, S., Pajares, J. 1992. Passivation of a montmorillonite by the silica created in acid activation. Journal of Material Chemistry, 2: 907-911.

Pushpaletha, P., Rugmini, S., Lalithambika, M. 2005. 
Correlation between surface properties and catalytic activity of clay catalysts. Applied Clay Science, 30: 141-153.

Sivakumar, P., Palanisamy, P.N. 2009. Adsorption studies of basic red 29 by a nonconventional activated carbon prepared from Euphorbia antiquorum L. International Journal of ChemTech Research, 1: 502-510.

Steudel, A., Batenburg, L.F., Fischer, H.R., Weidler, P.G., Emmerich, K. 2009. Alteration of swelling clay minerals by acid activation. Applied Clay Science, 44: 105-115.

Sumanjit, K., Walia, T.P.S., Mahanan, R.K. 2008. Comparative studies of zinc, cadmium, lead and copper on economically viable adsorbents. Journal of Environmental and Engineering Science, 7: 83-90.
Tsai, W.T., Hsu, H.S., Su, T.Y., Lin, K.Y., Lin, C.M., Dai, T.H. 2007. The adsorption of cationic dye from aqueous solution onto acid-activated andersite. Journal of Harzardous Materials, 147: 1056-1062. Vimonses, V., Lei, S., Jin, B., Chow, C.W.K., Saint, C. 2009. Kinetic study and equilibrium isotherm analysis of Congo red adsorption by clay materials. Chemical Engineering Journal, 148: 354-364.

Yan, L.G., Wang, J., Wei, H.Q., Du, B., Shan, X.Q. 2007. Adsorption of benzoic acid by CTAB exchanged montmorillonite. Applied Clay Science, 37: 226-230.

Zohra, B., Aicha, K., Fatima, S., Nourredine, B., Zoubir, D. 2008. Adsorption of Direct Red 2 on bentonite modified by cetyltrimethylammonium bromide. Chemical Engineering Journal,136: 295-305. 